\title{
FP Regimen
}

National Cancer Institute

\section{Source}

National Cancer Institute. FP Regimen. NCI Thesaurus. Code C63751.

A regimen consisting of fludarabine and prednisone used for the treatment of chronic lymphocytic leukemia. 